\title{
Production of strawberry cultivars in closed hydroponic systems and coconut fibre substrate ${ }^{1}$
}

\author{
Produção de cultivares morangueiro em sistemas hidropônicos fechados e substrato \\ de fibra de coco
}

\author{
Fabio Rodrigues de Miranda ${ }^{2 *}$, Valsérgio Barros da Silva ${ }^{3}$, Francisco Sérgio Ribeiro dos Santos ${ }^{4}$, Adroaldo \\ Guimarães Rossetti ${ }^{5}$ e Christiana de Fatima Bruce da Silva ${ }^{6}$
}

\begin{abstract}
The objective of this work was to evaluate yield and average fruit weight of strawberry cultivars Albion, Camarosa, Festival and Oso Grande, in two closed hydroponic systems (gutters and grow bags), using coconut fibre as substrate. The experimental design was of randomised blocks, divided into strips, with five replications. The hydroponic systems did not differ significantly as to yield, with advantages, such as savings in water and fertilizer and reduced environmental impact, over open systems. The most productive cultivar was Festival, followed by Oso Grande, with average yields of $6.99 \mathrm{~kg} \mathrm{~m}^{-2}$ and $5.56 \mathrm{~kg} \mathrm{~m}^{-2}$ respectively. The cultivars with the greatest fruit weight were Oso Grande and Albion, having averages of 11.8 and $11.1 \mathrm{~g}$ respectively, with the former being significantly superior to the latter. The highest yield $\left(7.4 \mathrm{~kg} \mathrm{~m}^{-2}\right)$ was obtained from the cultivar Festival under the gutter system. The Ibiapaba region has conditions which are favourable to strawberry production in relation to precocity (harvesting starts in the 6th week of growth) and production continues throughout the year; however there is a need to test new cultivars and to improve the cultivation techniques with an aim to producing larger-sized fruit.
\end{abstract}

Key words: Fragaria x ananassa. Hydroponics. Fertigation.

RESUMO - O objetivo do trabalho foi avaliar a produtividade e a massa média dos frutos das cultivares de morangueiro Albion, Camarosa, Festival e Oso Grande, em dois sistemas hidropônicos fechados (calhas e sacos de cultivo), utilizando como substrato a fibra de coco. O delineamento experimental foi de blocos casualizados, distribuídos em faixas, com cinco repetições. Os sistemas hidropônicos avaliados não diferiram significativamente entre si quanto à produtividade, com vantagens em relação aos sistemas abertos, como economia de água e fertilizantes e menor impacto ambiental. A cultivar mais produtiva foi a Festival, seguida pela Oso Grande (médias de 6,99 $\mathrm{kg} \mathrm{m}^{-2}$ e $5,56 \mathrm{~kg} \mathrm{~m}^{-2}$, respectivamente) e as cultivares com frutos de maior massa foram Oso Grande e Albion (médias de 11,8 e 11,1 g, respectivamente, sendo a primeira significativamente superior à segunda). A produtividade máxima $\left(7,4 \mathrm{~kg} \mathrm{~m}^{-2}\right)$ foi obtida com a cv. Festival no sistema de calhas. A região da Ibiapaba apresenta condições favoráveis para a produção de morango, com relação à precocidade (as colheitas iniciam na $6^{\mathrm{a}}$ semana de cultivo) e a produção contínua ao longo do ano, contudo há necessidade de testes de novas cultivares e melhoria das técnicas de cultivo, visando a produção de frutos de maior tamanho.

Palavras-chave: Morango. Hidroponia. Fertirrigação.

\footnotetext{
*Autor para correspondência

Recebido para publicação em 18/10/2013; aprovado em 27/06/2014

Pesquisa realizada com apoio financeiro do Banco do Nordeste do Brasil

${ }^{2}$ Embrapa Agroindústria Tropical, Rua, Dra. Sara Mesquita, 2270, Fortaleza-CE, Brasil, 60.511-110, fabio.miranda@embrapa.br

${ }^{3}$ Universidade Federal do Ceará, Fortaleza-CE, Brasil, sergiobarros62@ hotmail.com

${ }^{4}$ Departamento de Solos, Centro de Ciências Agrárias, Universidade Federal do Ceará, Fortaleza-CE, Brasil, sergio.cpm20@ hotmail.com

${ }^{5}$ Embrapa Agroindústria Tropical, Fortaleza-CE, Brasil, adroaldo.rossetti@embrapa.br

${ }^{6}$ Embrapa Agroindústria Tropical, Fortaleza-CE, Brasil, christiana.bruce@embrapa.br
} 


\section{INTRODUCTION}

Growing strawberries has aroused the interest of farmers of the Serra da Ibiapaba region of the state of Ceará, Brazil (CE). This is due to the low incidence of pests and diseases, and the consequently lower production costs compared to the traditional growing areas in the South and Southeast, in addition to the good prices obtained in regional markets. The system employed for strawberry production in the Ibiapaba region follows practices used in the Southeast, especially planting the cultivar Oso Grande in the soil, in beds covered with plastic mulch and tunnellike protective structures during the rainy season.

There are limitations when cultivating strawberries in the soil related to the prohibition of chemical fumigants for the control of phytopathogens and to the ergonomic difficulties of cultivating the plants on the ground surface, both of which have hampered the recruitment of manpower (GODOI et al., 2009).

Soiless growing systems in protected environments are said to be the trend for cultivation of the strawberry. When cultivation is carried out on benches above ground level, the job is easier and less unhealthy, the use of fumigant soil products is eliminated and there is a reduction in the occurrence of leaf diseases and consequently in the application of pesticides. Furthermore, there is an improvement in fruit quality, both sensory and from the point of view of chemical and microbiological contaminants (EMPRESA BRASILEIRA DE PESQUISA AGROPECUÁRIA, 2005).

It is however necessary to evaluate the real potential of soilless cultivation techniques for the strawberry, in relation to yield and to crop management, adapting techniques of hydroponic cultivation to tropical and subtropical conditions (FURLANI; FERNANDESJÚNIOR, 2004). Because of this, some studies have been carried out in Brazil using hydroponic systems, such as NFT (COSTA; LEAL, 2008; FERNANDES-JÚNIOR et al., 2002), or using substrates (CALVETE et al., 2007; COSTA; LEAL, 2008; FERNANDES-JÚNIOR et al., 2002; GODOI et al., 2009; RADIN et al., 2011).

Hydroponic systems can be closed, when the nutrient solution that passes through the roots returns to the reservoir, or open where the applied solution does not return to the reservoir (FERNANDES-JÚNIOR et al., 2002). Currently the predominant systems are open systems with drainage-loss of the nutrient solution, and cultivation in pots or bags using different substrates. However, due to economic and environmental issues, the trend is toward cultivation using a substrate in a closed system, with recirculation of the nutrient solution (LIETEN et al., 2004).
There is a need to develop systems that combine high yield with fruit quality, low cost and low impact on the environment. The systems to be developed should be of the closed type, using affordable substrates which are available in the region (GIMENEZ; ANDRIOLO; GODOI, 2008). Closed hydroponic systems, using carbonised rice hulls as substrate have been successfully tested for strawberry cultivation by Godoi et al. (2009) in southern Brazil.

In the northeast of Brazil coconut fibre is one of the more-available substrates. Coir is widely used as a substrate in the soilless cultivation of vegetables and flowers because of its physical and chemical characteristics, such as excellent porosity, lack of reaction to the nutrients from fertilization, long durability without alterations in its physical characteristics, the possibility of sterilisation and being an abundant and renewable raw material of low cost (CARRIJO; LIZ; MAKISHIMA, 2002).

This work aimed to evaluate the yield and average fruit weight of four strawberry cultivars under two closed hydroponic systems (gutters and grow bags), using coconut fibre as substrate, and to determine the crop water use efficiency.

\section{MATERIAL AND METHODS}

The experiment was carried out from May 2012 to February 2013 on private property located in Ibiapina, CE (latitude $3^{\circ} 58^{\prime} \mathrm{S}$, longitude $40^{\circ} 52^{\prime} \mathrm{W}$, at an altitude of $920 \mathrm{~m}$ ). The maximum daily temperatures at the site vary from 26 to $32{ }^{\circ} \mathrm{C}$, while the minimum daily temperatures range from 15 to $20^{\circ} \mathrm{C}$.

The treatments consisted of two closed hydroponic systems (gutters and grow bags) and four strawberry cultivars (Albion, Camarosa, Festival and Oso Grande), comprising a $2 \times 4$ factorial. An experimental design of randomised blocks was used, divided into strips, with five replications. The growing systems were arranged in the strips with the strawberry cultivars arranged in the plots.

Two wooden benches, $0.8 \mathrm{~m}$ high, $1.0 \mathrm{~m}$ wide and $24.0 \mathrm{~m}$ long, spaced $0.8 \mathrm{~m}$ apart were used to support the gutters and grow bags. The benches were installed under a high tubular tunnel structure of galvanized steel, $3 \mathrm{~m}$ wide and $2.5 \mathrm{~m}$ high, covered with $150 \mu \mathrm{m}$ milky color polyethylene film. On one of the benches, three rows of six gutters (Hidrogood ${ }^{\circledR}$ Horticultura Moderna Ltda.) were installed. The gutters were 4.0 $\mathrm{m}$ long, $0.22 \mathrm{~m}$ high and $0.17 \mathrm{~m}$ wide. Each gutter was filled with $26 \mathrm{~L}$ of coconut fibre substrate (Golden Mix 
Misto Type $80^{\circledR}$, Amafibra Fibras e Substratos Agrícola da Amazonia Ltda). On the other bench two rows of 20 grow bags containing a substrate of coconut fibre (BM Bioengineering Environmental Ltda) were arranged. The grow bags were made of black and white plastic and were $1.2 \mathrm{~m}$ long, $0.22 \mathrm{~m}$ wide and $0.12 \mathrm{~m}$ high.

For cultivation in gutters, the plants were spaced $0.30 \mathrm{~m}$ apart with $0.33 \mathrm{~m}$ between rows, giving a total of 12 plants per plot. For cultivation in grow bags, two bags were used per plot, spaced $0.5 \mathrm{~m}$ apart. In each bag eight seedlings were planted at a spacing of $0.15 \mathrm{~m}$ between rows and $0.30 \mathrm{~m}$ between plants in the form of a triangle, giving a total of 16 plants per plot.

Planting was done on 23 May 2012 using bare-root seedlings. Strawberry crop management was carried out following the recommendations of Bortolozzo et al. (2007). Stolons and aging leaves, or those presenting symptoms of disease, were removed weekly. Pests and diseases were controlled chemically as needed.

The nutrient solution recommended by Furlani and Fernandes-Júnior (2004) was used for fertigation. Application was by means of a recirculation system in which the solution was pumped from a fiberglass reservoir with a capacity of $5 \mathrm{~m}^{3}$, and applied by dripping (one emitter per plant, at a flow rate of $2 \mathrm{~L} \mathrm{~h}^{-1}$ ). Irrigation pulses with a duration of 5 min were applied (at a volume of $0.17 \mathrm{~L}$ per pulse per plant). The daily number of pulses ranged from one per day in the first days after transplanting the seedlings, to a maximum of six pulses per day from 110 days after transplanting (DAT). Volumes of nutrient solution in excess of the retention capacity of the substrate were collected from the gutters and grow bags with PVC pipes, and driven by gravity back to the reservoir. Every 15 days the remaining nutrient solution in the reservoir was discarded and replaced with fresh solution.

Table 1 shows the maximum and minimum values for $\mathrm{pH}$ and electrical conductivity (EC) of the nutrient solution measured during the experiment. For strawberry soilless cultivation, EC values of around $1.4 \mathrm{dS} \mathrm{m}^{-1}$ are indicated to obtain high yield and fruit quality (PARANJPE et al., 2003).

Harvests were held twice a week from 5July 2012 (43 DAT) to 22 February 2013 (275 DAT). For each harvest the number and weight of fruits were evaluated per plot, using an electronic scale accurate to $0.1 \mathrm{~g}$. The data were subjected to variance analysis. The averages for the cultivars were compared by Tukey test at 5\% probability, and the averages for the growing systems by F-test at the same level of significance.
Table 1 - Measured values for $\mathrm{pH}$ and electrical conductivity (EC) in closed hydroponic growing systems of gutters and grow bags

\begin{tabular}{lcc}
\hline \multicolumn{1}{c}{ Parameter } & Gutters & Grow Bags \\
\hline pH Nutrient Solution & $5.0-6.6$ & $5.0-6.6$ \\
pH Drainage & $5.1-6.7$ & $5.1-6.6$ \\
CE Nutrient Solution $\left(\mathrm{dS} \mathrm{m}^{-1}\right)$ & $1.2-1.8$ & $1.2-1.8$ \\
CE Drainage $\left(\mathrm{dS} \mathrm{m} \mathrm{m}^{-1}\right)$ & $1.0-2.2$ & $1.1-2.2$ \\
\hline
\end{tabular}

\section{RESULTS AND DISCUSSION}

In all the cultivars under test, both for the gutter system and for the grow bag system, harvests started in the 6 th week of cultivation (43 DAT), and even though it varied greatly, fruit production did not cease during the study period (Figures 1 and 2). This demonstrates the precocity and the possibility of producing strawberries throughout the year under the climatic conditions of the Serra da Ibiapaba, CE.

In the traditional strawberry growing regions in the South and Southeast of Brazil, the harvest begins between 60 and 80 days after transplanting the seedlings, depending on the climatic conditions, the type of soil, cultivation practices, method of seedling production and the cultivar (EMPRESA BRASILEIRA DE PESQUISA AGROPECUÁRIA, 2005). In some studies with the Camarosa, Festival and Oso Grande cultivars in the state of Rio Grande do Sul (RS), harvests began 90 to 120 days after transplanting the seedlings (CANSIAN et al., 2002; OLIVEIRA; SCIVITTARO; ROCHA, 2011), due to the climatic conditions and low temperatures in the region.

Figure 1 - Weekly fruit production of four strawberry cultivars grown in the hydroponic gutter system

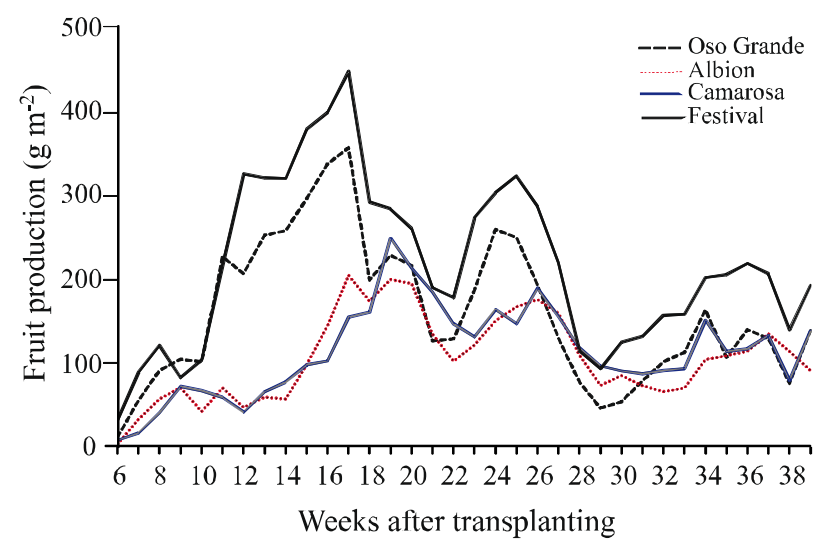


Figure 2 - Weekly fruit production of four strawberry cultivars grown in the hydroponic grow bag system

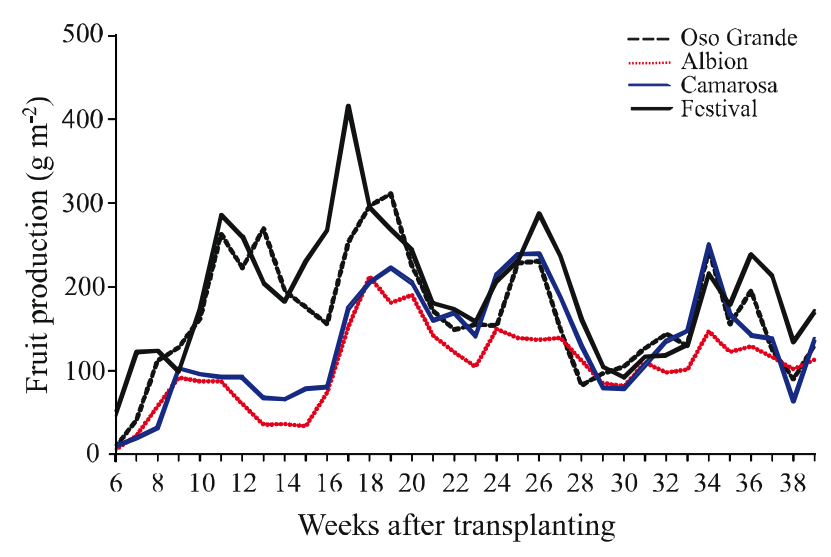

It can be seen in Figures 1 and 2 that up to the 20th week of cultivation, the Festival and Oso Grande cultivars had higher fruit production than the other cultivars. From the 21 st week of cultivation, the differences in production between the four cultivars were minimal. For the Festival and Oso Grande cultivars, peak production occurred between the 15th and 19th week of cultivation, while for the Camarosa and Albion cultivars, the period of greatest production occurred between the 17 th and 20th weeks. After the first peak in production, smaller peaks were recorded every 10 weeks on average. Similar behaviour for the occurrence of peak strawberry production has been observed in other regions by Cansian et al. (2002) and Fernandes-Júnior et al. (2002).

Fruit production and quality in the strawberry are influenced by the interaction between photoperiod and temperature. Short-day cultivars, such as Oso Grande, Camarosa and Festival, begin flowering under conditions of a short photoperiod (usually less than 12 hours) and low temperatures. The day-neutral cultivars, such as Albion, are not dependent on the length of the day to initiate flowering, which even takes place during the summer. (EMPRESA BRASILEIRA DE PESQUISAAGROPECUÁRIA, 2005).

The short-day cultivars under high-temperature conditions and long days, present greater vegetative growth at the expense of reproductive growth. Because of this, in the South and Southeast of Brazil the supply of fruit on the market is less from November until the beginning of winter. In contrast, day-neutral cultivars give increased production during the warmer periods of the year, as they are less sensitive to the stimuli that the photoperiod and temperature have on the production of stolons, and can thus extend their fruiting period (STRASSBURGER et al., 2010).
Temperature is the main climate variable to affect the strawberry plant, changing its vegetative and reproductive behaviour. Under high-temperature conditions, flowering ceases and the strawberry tends to reproduce by vegetative growth, accelerating the production of a large numbers of stolons (ALMEIDA et al., 2009). According to Ledesma, Nakata and Sugiyama (2008), the optimum temperature range for the development of the strawberry varies from 10 to $26{ }^{\circ} \mathrm{C}$. Stress conditions such as extreme temperatures, water deficit and low solar radiation or deficient pollination are decisive factors in floral abscission and consequently in reducing the number of fruit.

During the experiment, sunshine at the site ranged from 11 to 12 hours per day. From July 2012 to May 2012, the maximum temperatures under the plastic tunnel were favourable to the crop, not exceeding $28^{\circ} \mathrm{C}$. After the end of the rainy season (from August 2012), the maximum daily temperature ranged from 31.1 to $32.2{ }^{\circ} \mathrm{C}$. It is probable that the fall in production of the strawberry cultivars from the 20th week of cultivation (October 2012) is associated with the increase in temperatures that occurred from August 2012. According to Antunes et al. (2006), it takes about 40 days from the appearance of the flower buds to harvesting the fruit, for the Oso Grande cultivar.

Table 2 shows the results of variance analysis of the production data. There were significant differences between the hydroponic growing systems for the variables yield per plant and average fruit weight. Differences, significant to $1 \%$ probability, were observed between the strawberry cultivars for all variables. For the interaction between growing system and cultivar, significant differences were observed only for the variable of yield per plant.

The Albion and Camarosa cultivars presented lower yields $\left(\mathrm{g} \mathrm{m}^{-2}\right)$ than the Oso Grande and Festival cultivars under both hydroponic systems (Table 3 ). The Festival cultivar was superior to the others under the gutter system, followed by Oso Grande. Under the grow bag system however, there was no significant difference between those two cultivars and both were superior to cultivars Camarosa and Albion.

Comparing yield for the four cultivars under the two growing systems, only the Festival cultivar displayed a significant difference, with a higher average yield under the gutter system in relation to the grow bags. For the other cultivars, no significant differences in yield between the two systems were detected.

The Camarosa cultivar is one of the most planted in southern Brazil (OLIVEIRA; SCIVITTARO; FINKENAUER, 2008), while in the rest of the country Oso Grande is of greater economic importance (ANTUNES; REISSER JÚNIOR, 2007). In the Ibiapaba region, the 
Table 2 - Mean squares and significance levels from variance analysis of the data

\begin{tabular}{|c|c|c|c|c|}
\hline \multirow{2}{*}{ Source of Variation } & \multirow{2}{*}{$\mathrm{DF}$} & \multicolumn{3}{|c|}{ 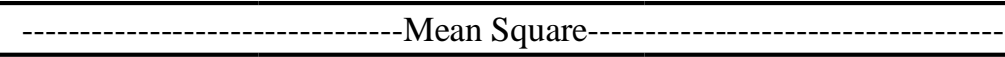 } \\
\hline & & Yield $\left(\mathrm{g} \mathrm{m}^{-2}\right)$ & Yield per plant $\left(\mathrm{g} \mathrm{plant}^{-1}\right)$ & Average fruit weight $(\mathrm{g})$ \\
\hline Block & 4 & - & - & - \\
\hline Hydroponic system (S) & 1 & $2.03^{\mathrm{ns}}$ & $530,611.22 * *$ & $0.99 *$ \\
\hline Error & 4 & $486,590.71$ & $9,952.85$ & 0.08 \\
\hline Cultivar (C) & 3 & $23,163,226.89 * *$ & $645,348.22 * *$ & $33.16 * *$ \\
\hline Error & 12 & $278,745.25$ & $8,734.10$ & 0.11 \\
\hline Interaction $\mathrm{S} \times \mathrm{C}$ & 3 & $953,034.96^{\mathrm{ns}}$ & $77,722.69 * *$ & $0.17^{\mathrm{ns}}$ \\
\hline Error & 12 & $330,854.90$ & $9,157.90$ & 0.11 \\
\hline $\mathrm{CV}(\%)$ & & 11.34 & 11.27 & 3.81 \\
\hline Mean & & $5,073.33$ & 848.92 & 10.12 \\
\hline
\end{tabular}

** Significant at a level of $1 \%$ probability $(p<0.01) . *$ Significant at a level of $5 \%$ probability $(0.01<p<0.05)$. ns: not significant at a level of $1 \%$ probability $(p>0.05)$

Table 3 - Yield $\left(\mathrm{g} \mathrm{m}^{-2}\right)$ of four strawberry cultivars under two hydroponic growing systems

\begin{tabular}{lccc}
\hline \multicolumn{1}{c}{ Cultivar } & Gutters & Grow Bags & Mean \\
\hline Albion & $3,600.4 \mathrm{cA}$ & $3,576.0 \mathrm{bA}$ & $3,588.2 \mathrm{~d}$ \\
Camarosa & $3,844.4 \mathrm{cA}$ & $4,466.4 \mathrm{bA}$ & $4,155.4 \mathrm{c}$ \\
Festival & $7,405.0 \mathrm{aA}$ & $6,568.4 \mathrm{aB}$ & $6,986.7 \mathrm{a}$ \\
Oso Grande & $5,444.4 \mathrm{bA}$ & $5,681.6 \mathrm{aA}$ & $5,563.0 \mathrm{~b}$ \\
Mean & $5,073.6 \mathrm{~A}$ & $5,073.1 \mathrm{~A}$ & $5,073.3$ \\
CV $(\%)$ & 11.8 & 9.9 & 11.3 \\
\hline
\end{tabular}

Means followed by the same lowercase letters in a column do not differ by Tukey test at a level of $5 \%$ probability and those followed by uppercase letters on a line do not differ by F-test at the same level of probability

Oso Grande cultivar is preferred by farmers as it is one of the most disease-resistant, producing fruit of a size and appearance suitable for the fresh-fruit market.

The yield achieved in this study with the Festival and Oso Grande cultivars is comparable with those obtained in Europe under hydroponic systems using substrates, which according to Gimenez, Andriolo and Godoi (2008), range from 5 to $10 \mathrm{~kg} \mathrm{~m}^{-2}$. According to Paranjpe et al. (2003), in Florida, the use of protected-cultivation technology, together with selected cultivars, appropriate cultivation methods and integrated pest and disease management, allow to achieve yields of 7 to $9 \mathrm{~kg} \mathrm{~m}^{-2}$.

As regards the other studies conducted in Brazil; the maximum yield obtained in this study $\left(7.4 \mathrm{~kg} \mathrm{~m}^{-2}\right.$ for the Festival cultivar under the gutter system) was higher than those obtained for crops grown in the ground in southern Brazil by Virmond and Resende (2006) (5.5 and $5.7 \mathrm{~kg} \mathrm{~m}^{-2}$ for the Oso Grande and Camarosa cultivars respectively) and by Cansian et al. (2002) (1.8 to $2.6 \mathrm{~kg} \mathrm{~m}^{-2}$ for the Oso Grande and Camarosa cultivars respectively). In the state of Paraná (PR), Resende et al. (2010) observed no significant differences in yield between the Camarosa and Oso Grande cultivars, obtaining yields of 5.7 and $5.5 \mathrm{~kg} \mathrm{~m}^{-2}$ respectively. In an open hydroponics system using grow bags containing commercial organic substrate, Andriolo, Boemo and Bonini (2002) obtained an average yield of $4.0 \mathrm{~kg} \mathrm{~m}^{-2}$ for the Dover cultivar in Santa Maria, RS; lower than those obtained in this research.

The yield per plant under the hydroponic gutter system was significantly higher than that obtained with the grow bags (Table 4). These differences are probably due to the lower plant density in the gutters in relation to the grow bags.

Using closed hydroponic systems with a commercial substrate, Godoi et al. (2009) obtained greater yield per plant in grow bags in relation to cultivation in gutters. Under both systems the authors used a planting 
density of 12 plants $\mathrm{m}^{-2}$. In the present study, the planting densities were 13 plants $\mathrm{m}^{-2}$ for cultivation in grow bags and 10 plants $\mathrm{m}^{-2}$ for the gutters.

The Festival cultivar presented the highest yield per plant followed by the Oso Grande cultivar. The Albion and Camarosa cultivars did not adapt adequately to the climate of the Ibiapaba region with significantly lower yields per plant than the other cultivars. These results are in contrast with those obtained by Oliveira, Scivittaro and Rocha (2011) for ground cultivation in the region of Pelotas RS, where the Camarosa cultivar showed higher yield per plant than did the Festival cultivar (1,156 and $774 \mathrm{~g} \mathrm{plant}^{-1}$ respectively).

Studying the interaction between growing system and cultivar, it was found that under the gutter system, except for the Camarosa cultivar, significantly higher averages were obtained in relation to the grow bag system for the variable of yield per plant (Table 4). Even without this significant difference the Camarosa cultivar also performed better under the gutter system.

The maximum yield per plant obtained in the present study with the Festival cultivar grown in gutters $\left(1,407 \mathrm{~g} \mathrm{plant}^{-1}\right)$, was higher than those obtained by Godoi et al. (2009) in closed hydroponic systems with the Arazá cultivar (1,065 $\mathrm{g}$ plant $^{-1}$ and $845 \mathrm{~g} \mathrm{plant}^{-1}$ in bags and gutters respectively). The results for yield per plant of the Oso Grande and Camarosa cultivars obtained in the present study, were higher than those obtained by Radin et al. (2011) (241.9 and 225.8 g plant $^{-1}$ with the Oso Grande and Camarosa cultivars respectively) and by Calvete et al. (2007) (187.9 g plant $^{-1}$ for Oso Grande) under open hydroponic systems in the state of Rio Grande do Sul.

In practice, a yield of $300 \mathrm{~g} \mathrm{plant}^{-1}$ is considered as being the threshold for economic viability for strawberries grown in the soil (OLIVEIRA; SCIVITTARO, 2011). For the grow bag system,
Bortolozzo et al. (2007) consider an average yield of $1,200 \mathrm{~g} \mathrm{plant}^{-1}$ as satisfactory.

The gutter system presented fruits of greater weight compared to the grow bag system (Table 5). This can be attributed to the lower plant density used in the gutter system. The Oso Grande cultivar presented fruits of significantly greater weight than the other cultivars, followed by Albion and Festival. The Camarosa cultivar, despite appearing to have greater vigour in relation to the other cultivars, produced fruits of lesser weight.

The fruit in this study presented lower values for average weight than those obtained for the same cultivars in the South and Southeast of Brazil. Virmond and Resende (2006) obtained values for average fruit weight with the Oso Grande and Camarosa cultivars, grown in the soil, of 13.8 and $14.7 \mathrm{~g}$ respectively in the state of Paraná. Resende et al. (2010) obtained values for average weight of 16.5 and $16.3 \mathrm{~g}$ respectively in the Camarosa and Oso Grande cultivars also grown in the soil in Paraná. Oliveira, Scivittaro and Rocha (2011) got fruit with an average weight of 27.9 and $24.9 \mathrm{~g}$ with the Camarosa and Festival cultivars respectively in Pelotas, RS. However, Camargo et al. (2010) obtained fruit from the Oso Grande cultivar with an average weight of only $8.78 \mathrm{~g}$ when grown in the soil in Guarapuava, PR.

Such behaviour with respect to the fruit size (weight) may be related to adaptation by the cultivars to the climatic characteristics of the region. According to Conti, Minami and Tavares (2002), a complex interaction between temperature and length of day determine production performance and fruit quality in strawberry cultivars in any given producing region. In view of this, when a cultivar has been selected for a given physiographic region and planted in another, it is unlikely to have a high yield of quality fruit. The authors evaluated five strawberry cultivars in regions of mild climate (Atibaia, São Paulo) and hot climate

Table 4 - Fruit yield (g plant ${ }^{-1}$ ) of four strawberry cultivars under two hydroponic growing systems

\begin{tabular}{lccc}
\hline \multicolumn{1}{c}{ Cultivar } & Gutters & Grow Bags & Mean \\
\hline Albion & $684.4 \mathrm{cA}$ & $509.6 \mathrm{cB}$ & $597.0 \mathrm{c}$ \\
Camarosa & $730.4 \mathrm{cA}$ & $679.6 \mathrm{bA}$ & $705.0 \mathrm{c}$ \\
Festival & $1,407.0 \mathrm{aA}$ & $936.0 \mathrm{aB}$ & $1,171.5 \mathrm{a}$ \\
Oso Grande & $1,034.6 \mathrm{bA}$ & $809.8 \mathrm{abB}$ & $922.2 \mathrm{~b}$ \\
Mean & $964.1 \mathrm{~A}$ & $733.8 \mathrm{~B}$ & 848.9 \\
$\mathrm{CV}(\%)$ & 11.8 & 9.6 & 11.3 \\
\hline
\end{tabular}

Means followed by the same lowercase letters in a column do not differ by Tukey test at a level of 5\% probability and those followed by uppercase letters on a line do not differ by F-test at the same level of probability 
Table 5 - Average fruit weight $(\mathrm{g})$ in four strawberry cultivars under two hydroponic growing systems

\begin{tabular}{lccc}
\hline \multicolumn{1}{c}{ Cultivar } & Gutters & Grow Bags & Mean \\
\hline Albion & $11.40 \mathrm{aA}$ & $10.81 \mathrm{bA}$ & $11.10 \mathrm{~b}$ \\
Camarosa & $7.66 \mathrm{cA}$ & $7.69 \mathrm{dA}$ & $7.68 \mathrm{~d}$ \\
Festival & $9.64 \mathrm{bA}$ & $9.35 \mathrm{cA}$ & $9.50 \mathrm{c}$ \\
Oso Grande & $11.96 \mathrm{aA}$ & $11.55 \mathrm{aA}$ & $11.76 \mathrm{a}$ \\
Mean & $10.17 \mathrm{~A}$ & $9.85 \mathrm{~B}$ & 10.12 \\
CV $(\%)$ & 3.99 & 2.43 & 3.81 \\
\hline
\end{tabular}

Means followed by the same lowercase letters in a column do not differ by Tukey test at a level of $5 \%$ probability and those followed by uppercase letters on a line do not differ by F-test at the same level of probability

(Piracicaba, São Paulo), and concluded that there was greater fruit production, with greater average fruit weight, in the region of mild climate.

Analysing the variations in fruit weight throughout the cycle of the strawberry (Figures 3 and 4), it can be seen that the fruit reached its greatest average weight between the ninth and twelfth week after the seedlings were transplanted. From then on there was a reduction in fruit size for all cultivars and growing systems. The Oso Grande and Albion cultivars produced fruit of greater weight compared to the other cultivars for almost the whole crop cycle.

It is likely that the reduction in fruit weight from August 2012 is related to an increase in temperature. According to Ledesma, Nakata and Sugiyama (2008), temperatures above $30^{\circ} \mathrm{C}$ may cause a reduction in the size and weight of fruits in the strawberry. Comparing the yield of strawberry cultivars under different temperature conditions, the authors observed that the number of inflorescences, the number of fruits and the average fruit weight were all significantly lower when the day/night temperature ratio was $30 / 25^{\circ} \mathrm{C}$ compared to $23 / 18^{\circ} \mathrm{C}$.

Another likely cause of the drop in production and average fruit weight of the strawberry concerns an attack by mites from October 2012 which, because of the hot, dry climate, proved difficult to control.

The established marketing threshold for extratype strawberries is $14 \mathrm{~g}$ (OLIVEIRA; SCIVITTARO, 2011). In the present study, higher averages than $14 \mathrm{~g}$ per fruit were obtained until the 17th week of growth only, and mainly with the Oso Grande and Albion cultivars. According to Strassburger et al. (2010), the main difficulties faced by farmers in producing strawberries outside the traditional growing season, are in obtaining adequate yield and harvesting fruits of a satisfactory size.
Figure 3 - Variation in average fruit weight (g) of four strawberry cultivars grown in the hydroponic gutter system

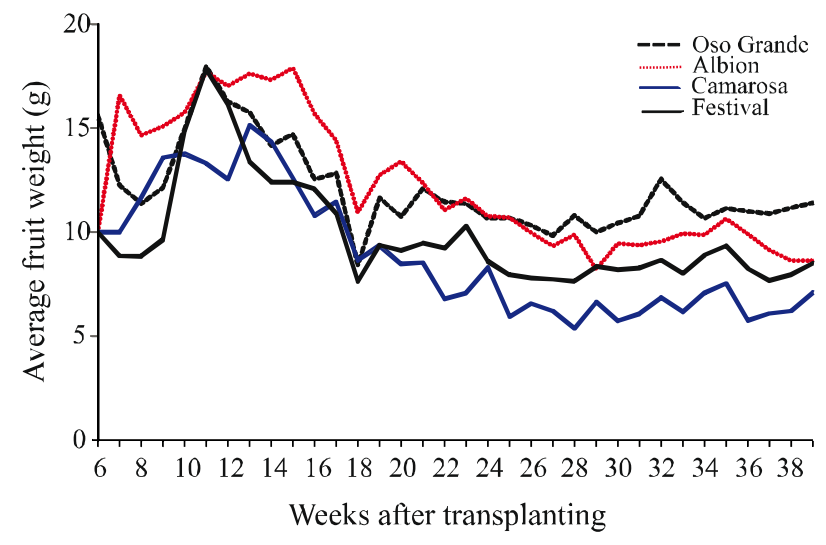

Figure 4 - Variation in average fruit weight $(\mathrm{g})$ of four strawberry cultivars grown in the hydroponic grow bag system

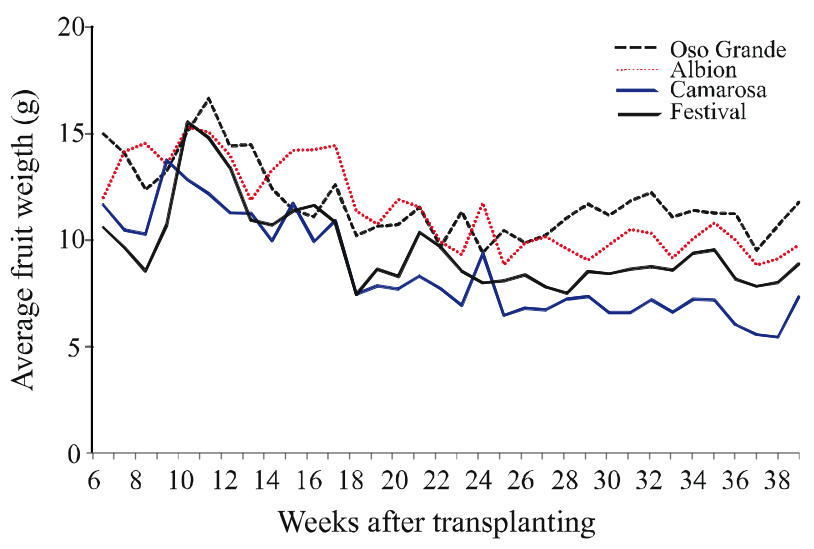


During the cycle of the strawberry (274 days), the total consumption of nutrient solution was $101 \mathrm{~L} \mathrm{plant}^{-1}$ and $98 \mathrm{~L} \mathrm{plant}^{-1}$ for the systems of gutters and grow bags respectively. Average values for water use efficiency of 8.7 and $6.8 \mathrm{~g}$ fruit per litre of nutrient solution consumed were observed for the gutters and grow bags systems respectively. These values for water use efficiency are higher than those observed by Kirschbaum et al. (2004) for cultivation in the soil ( 4.0 to $\left.4.5 \mathrm{~g} \mathrm{~L}^{-1}\right)$.

It is noteworthy that closed hydroponic systems, such as used in this study, exhibit reductions in water and fertilizer consumption that can vary from 20 to $50 \%$ compared to open hydroponic systems, since with the latter an excess of nutrient solution of the order of 20 to $50 \%$ is applied to control the salinity of the substrate (LIETEN et al., 2004). If this excess is not used for other crops, there is a reduction in the efficient use of water and nutrients with pollution of the soil and groundwater, which is why some countries have banned the use of open soilless growing systems.

\section{CONCLUSIONS}

1. Closed hydroponic systems of gutters and grow bags present similar and satisfactory strawberry yields, with advantages over open systems, such as the savings in water and fertiliser and less environmental impact;

2. Of the strawberry cultivars evaluated, the most productive under the climatic conditions of the Serra da Ibiapaba, $\mathrm{CE}$, is the cultivar Festival, followed by Oso Grande; the cultivars having greater fruit mass are Oso Grande and Albion;

3. The Ibiapaba region displays favourable conditions for strawberry production in terms of precocity and continuous production throughout the year, however there is a need to test new cultivars and to improve the growing system, with a view to producing larger fruit.

\section{ACKNOWLEDGEMENTS}

The authors wish to thank the Banco do Nordeste do Brasil for their financial support of this research.

\section{REFERENCES}

ALMEIDA, I. R. et al. Potenciais regiões produtoras de morango durante a primavera e verão e riscos de ocorrência de geada na produção de inverno no estado do Rio Grande do
Sul. Pelotas: Embrapa Clima Temperado, 2009. 5 p. (Embrapa Clima Temperado. Comunicado Técnico, 229).

ANDRIOLO, J. L.; BONINI, J. V.; BOEMO, M. P. Acumulação de matéria seca e rendimento de frutos de morangueiro cultivado em substrato com diferentes soluções nutritivas. Horticultura Brasileira, v. 20, n. 1, p. 24-27, 2002.

ANTUNES, O. T. et al. Floração, frutificação e maturação de frutos de morangueiro cultivados em ambiente protegido. Horticultura Brasileira, v. 24, n. 4, p. 426-430, 2006.

ANTUNES, L. E. C.; REISSER JÚNIOR, C. Fragole, i produttori brasiliani mirano all esportazione in Europa. Rivista di Frutticoltura e di Ortofloricoltura, v. 69, n. 5, p. 60-65, 2007.

BORTOlOZZO, A. R. et al. Produção de morangos no sistema semi-hidropônico. Bento Gonçalves: EmbrapaUva e Vinho, 2007. 24 p. (Embrapa-Uva e Vinho. Circular Técnica, 62).

CALVETE, E. O. et al. Produção hidropônica de morangueiro em sistema de colunas verticais, sob cultivo protegido. Revista Brasileira de Fruticultura, v. 29, n. 3, p. 524-529, 2007.

CAMARGO, L. K. P. et al. Desempenho produtivo e massa média de frutos de morangueiro obtidos de diferentes sistemas de cultivo. Ambiência Guarapuava, v. 6, n. 2, p. 281-288, 2010.

CANSIAN, R. L. et al. Comportamento de cultivares de morango (Fragaria $x$ ananassa Duch) na região do Alto Uruguai do Rio Grande do Sul. Revista Brasileira de Agrociência, v. 8, n. 2, p. 103-105, 2002.

CARRIJO, O. A.; LIZ, R. S.; MAKISHIMA, N. Fibra da casca do coco verde como substrato agrícola. Horticultura Brasileira, v. 20, n. 4, p. 533-535, 2002.

CONTI, J. H.; MINAMI, K.; TAVARES, F. C. A. Produção e qualidade de frutos de morango em ensaios conduzidos em Atibaia e Piracicaba. Horticultura Brasileira, v. 20, n. 1, p. 10-17, 2002.

COSTA, E.; LEAL, P. A. M. Avaliação de variedades de morangueiro em sistemas hidropônicos sob casa de vegetação. Revista Brasileira de Fruticultura, v. 30, n. 2, p. 425-430, 2008.

EMPRESABRASILEIRADEPESQUISAAGROPECUÁRIA. Sistema de produção do morango: cultivo protegido. Sistemas de Produção 5, 2005. Disponível em:< http:// sistemasdeproducao.cnptia.embrapa.br/FontesHTML/ Morango/SistemaProducaoMorango/index.htm>. Acesso em: 12 ago. 2013

FERNANDES-JÚNIOR, F. et al. Produção de frutos e estolhos do morangueiro em diferentes sistemas de cultivo em ambiente protegido. Bragantia, v. 61, n. 1, p. 25-34, 2002.

FURLANI, P. R.; FERNANDEZ JÚNIOR, F. Cultivo hidropônico de morango em ambiente protegido. In: SIMPÓSIO NACIONAL DO MORANGO; ENCONTRO DE PEQUENAS FRUTAS E FRUTAS NATIVAS DO 
MERCOSUL, 2., 2004, Pelotas. Anais... Pelotas: Embrapa Clima Temperado, 2004. p. 102-115.

GIMENEZ, G.; ANDRIOLO, J. L.; GODOI, R. S. Cultivo sem solo do morangueiro. Ciência Rural, v. 38, n. 1, p. 273279, 2008.

GODOI, R. S. et al. Produção e qualidade do morangueiro em sistemas fechados de cultivo sem solo com emprego de substratos. Ciência Rural, v. 39, n. 4, p. 1039-1044, 2009.

KIRSCHBAUM, D. S. et al. Water requirement and water use efficiency of fresh and waiting-bed strawberry plants. Acta Horticulturae, v. 664, n. 1, p. 347-352, 2004.

LEDESMA, N. A.; NAKATA, M.; SUGIYAMA, N. Effect of high temperature stress on the reproductive growth of strawberry cvs. 'Nyoho' and 'Toyonoka'. Scientia Horticulturae, v. 116, n. 2, p. 186-193, 2008.

LIETEN, F. et al. Recent situation of strawberry substrate culture in Europe. Acta Horticulturae, v. 649, p.193-196, 2004.

OLIVEIRA, R. P.; SCIVITTARO, W. B.; FINKENAUER, D. Produção de morangueiro da cv. Camino Real em sistema de túnel. Revista Brasileira de Fruticultura, v. 30, n. 3, p. 681-684, 2008.
OLIVEIRA, R. P.; SCIVITTARO, W. B. Desempenho produtivo de cultivares de morangueiro. Scientia Agraria, v. 12, n. 2, p. 69-074, 2011.

OLIVEIRA, R. P.; SCIVITTARO, W. B.; ROCHA, P. S. G. Produção de cultivares de morango, utilizando túnel baixo em Pelotas. Revista Ceres, v. 58, n. 5, p. 625-631, 2011.

PARANJPE A. et al. Winter strawberry production in greenhouses using soilless substrates: an alternative to methyl bromide soil fumigation. Proceedings of the Florida State for Horticultural Science, v. 116, n. 1, p. 98-105, 2003.

RADIN, B. et al. Desempenho de quatro cultivares de morangueiro em duas regiões ecoclimáticas do Rio Grande do Sul. Horticultura Brasileira, v. 29, n. 3, p. 287-291, 2011.

RESENDE, J. T. V. et al. Produtividade e teor de sólidos solúveis de frutos de cultivares de morangueiro em ambiente protegido. Horticultura Brasileira, v. 28, n. 2, p. 185-189, 2010.

STRASSBURGER, A. S. et al. Crescimento e produtividade de cultivares de morangueiro de "dia neutro" em diferentes densidades de plantio em sistema de cultivo orgânico. Bragantia, v. 69, n. 3, p. 623-630, 2010.

VIRMOND, M. F. R.; RESENDE, J. T. V. Produtividade e teor de sólidos solúveis totais em frutos de morango sob diferentes ambientes de cultivo. Revista Eletrônica Lato Sensu - Ciências Agrárias, v. 1, n. 1, p. 62-69, 2006. 